\title{
The Adipati Karna's Morality Due to Kresna Duta By Ki Narto Sabdo
}

\author{
Suyatno1, Supardjo2, Sutarjo3 \\ \{suyatno_sasda@staff.uns.ac.id\}
}

Sastra Daerah FIB UNS

\begin{abstract}
Adipati Karna remained adamant on his stand that in the Baratayuda war would remain for Kurawa. From the description above there are some questions arises: is there any value attached to Adipati Karna because it makes him firm to one's stand? Is there worth of worth that Adipati Karna has been willing to sacrifice his soul and his body? The problem is a moral matter, and it is of interest to be considered from a moral standpoint, so the writer is interested in examining Adipati Karna's morality as a great figure in the war of Baratayuda. Material object in this research is the moral conduct of Adipati Karna. The data source in this research are drawn from the story of the purwa puppetry (Wayang Purwa) in the story of Kresna Duta presented by Ki Narto Sabdo who lived in 1925 to 1985. From the description above, Adipati Karna was a knight and a warlord or kurawa's rifle. On the verge of the battle of the baratayuda Adipati Karna to reveal his true identity as a knight. That existence is categorized as the three marks of moral value, those relating to duty, responsibility, and honesty.
\end{abstract}

Keywords: Adipati Karna, morality, Narto Sabdo, purwa puppetry.

\section{Introduction}

Adipati Karna, Karna Basusena, Suryaputra, Suryaatmaja is the name of the son of Kunti with Dewa Surya, a figure in the Baratayuda war. He was raised as a child by Adirata and his wife Radha, so Adipati Karna was called Radheya. Adirata is a coachman of king Drestarastra. When 16-year-old Radheya was bought by Adirata in his own chariot and horses, but his interest was in the sciences of war and archery. At the time in Hastina country, Radheya came to the tournament, although not invited. At the start of the tournament, Radheya was not allowed to participate because she was not a descendant of knights or brahmins. However, due to king Duryudana's good graces, Radheya was made king of stairs with a raja Angga title and was therefore able to enter the tournament [1].

When Baratayuda's war of Adipati Karna was raised by the King Duryudana as the warlord of the Kurawa's, it means that Adipati Karna corrupt of Kurawa. Adipati Karna is the first child of Kunti and as the oldest brother of Pandawa. Baratayuda war was a war between Kurawa and Pendawa. According to Ki Nartosabdo, in the story of Kresna Duta, a large war in the pempan is there 12 (twelve) times, whichis only fired four times, namely: Gojalisuta, Guntarayana, Pamuksa, and Baratayuda.

On the verge of the Baratayuda Adipati Karna having a two-time debate over the issue of morality to which to judge. First argument with the King Kresna and second argument with his 
own mother called kunti. In this debate both of Kresna and kunti had the same aim, to persuade Adipati Karna to change his mind to join the Pandawa. But Kresna and Kunti's efforts to persuade Adipati Karna for total failure. Adipati Karna remained adamant on his stand that in the Baratayuda war would remain for Kurawa.

From the description above there are some questions arises: is there any value attached to Adipati Karna because it makes him firm to one's stand? Is there worth of worth that Adipati Karna has been willing to sacrifice his soul and his body? The problem is a moral matter, and it is of interest to be considered from a moral standpoint, so the writer is interested in examining Adipati Karna's morality as a great figure in the war of Baratayuda.

\section{Research Methods}

Material object in this research is the moral conduct of Adipati Karna. The data source in this research are drawn from the story of the purwa puppetry (Wayang Purwa) in the story of Kresna Duta presented by Ki Narto Sabdo who lived in 1925 to 1985 . The data source that is used in the research is in the form of audio tapes that are fed by mediates in the form of soft files /flash discs, and those that have been fed into the computer. In the story of the Kresna Duta delivered behind ki narto sabdo was eight audio tapes, and it was delivered in 461 minutes.

The story entitled Kresna Duta is divided into eight, they are, the scene of the state of Wirata, Hastina, the herot of the Ukiratawu, Setragandamayit, the kresna dialogue- Adipati Karna in the chariot of Adipati Karna, Kunti dialogue-the war started with the appearance of Setra, north, the thinning, and the losing of bisma's arrows. The Kresna Duta story is over. Of the eight scenes, the research will focus on the involvement of Adipati Karna as in the Hastina state scene, the dialogue between kresna - Adipati Karna of beacones in Adipati Karna's car of calah, and the kunti dialogues - Adipati Karna in Pangombakan of the Yamawidura place.

\section{Results and Discussion}

\section{Formal Objects}

The formal object in this research is a moral value. The moral value comes from two words, there are values and morals. Value is the subject of action of actionology. Actionology assesses about the values or precious of something [2]. The nature of value is the quality that is contained on a thing so that makes it as a destination and object of interest. The value gives motivation to human behavior so that people are trying to fight for, and after being achieved to keep it.

The value is classified into the value of truth-reality, the value of goodness, the value of beauty, and religious values. The value of the truth-reality is the value relating to the knowledge and the process of thinking (reasoning). The values of the truth-reality are the main theme in the epistemology and logic philosophical branch. The value of goodness is the value associated with human will. The value of goodness becomes the main theme of the conversion in moral philosophy. The value of beauty is a value related to sensing (perchonian), pleasure, and satisfaction. The value of beauty becomes the main theme in the branch of philosophy of beauty. And the religious value is the value concerned with human beliefs to God, namely human relationship with God in the form of dedication and mindset, attitude, and deeds as a manifestation of the devotion [2]. 
Morals are good based on moral values says moral values always refer to the person as a person. The moral nature of human life is seen in its goodness as a human [3][4]. Mudhofir in the "Kamus Etika" says that morals mean those concerned with seemingly innocent human activities [5]. Furthermore, in the same book, it is said that morals conform to accepted rules of what is looked good (righteous, just, decent). Of these, it can be said that moral principles are good, appropriate that are used for human guidelines of conduct. When linked to moral value means the value of something good, good, proper that is used as a guide to human conduct.

Moral values have such characteristics as responsibility, obligation, and conscience. The moral values that bear on responsibility can only be embodied in the deeds that are fully the responsibility of the person. That depends on his freedom. Freedom and responsibility are absolute prerequisites. Then oblige. To obligate means to obligate us absolutes and inexpertly. Obliging can be defined as ordering in English which is inproductive. It means that moral values are just what we are, unconditional. Whereas conscience comes from the root of human autonomy, the center of independence, an element that does not allow a human to become a crucible ora buffalo that is easily led in the opinions of others. Conscience is the piece DE resistance, an element of resistance that will interfere with riot-suseno harmony [6]. If conscience is translated with honesty, then moral worth is associated with duty, responsibility, and honesty. Moral obligation there is willingness to act; Responsibility was the result of his decision; And honesty is an attitude based on reality and not on lies.

\section{Review measures}

First, the act of Kresna Duta mastermind Ki Narto Sabdo, listened carefully and carefully [7]. Second, the Dramamine story is transcribed, which means that audio data has been converted into written data. Third, the display of data and the reduction of data already collected is grouped into several sets of insights. Fourth, analyze the detailed data for being a clear and valid understanding. Fifth, conclusion.

\section{The Story Outline of Kresna Duta According to Ki Narto Sabdo}

The state of Wirata with Prabu Matswapati as the king met with Pandawa and Prabu Kresna, to discuss the return of half the state of Hastina and Ngendraprasta and share to the Pandawa from kurawa. Pandawa twice sent ambassadors to Hastina, Kunti and Prabu Drupada, but both of them are failed to get a respite statement from Prabu Duryudana. Having already failed twice, Pandawa requested that the Prabu Kresna from Dwarawati state become the last ambassador to Hastina for the declaration of return of half the Hastina and Ngendraprasta kingdom and its removal from the Prabu Duryudana, but the Prabu Kresna's efforts have been unsuccessful. Duryudana authorities state that Hastina state is maintained at the risk of duryudana's neck. Prabu kresna's failure and the duryudana's statement suggest that the Baratayuda war is inevitable, and it will be.

Because bratayuda was sure to happen, so pabu kresna tried and succeeded to meet with the duke because of the awangga state, to invite him to join and side with pandawa. The duke was adamant on his stand, that in the war of baratayuda followed kurawa as an instrument of war. Before going into battle, the duke accomplished his earthly ministry. But before engaging in arms, the duke went to see his mother kunti to give her last worship and asked her blessing as a knight who would perform a sacred duty, battle on the field. During the meeting kunti persuaded the duke to join his brothers and sisters of the pandavas, but the kunti's efforts failed. Before stepping onto the battlefield, the duke of asbowing to the throne and swearing would not bring the end to the throne, if the blood in the kurusetra had not yet flooded up into the knees, 
sarah kuwanda, ganggeng rambut, krikil untu [8]. In the baratayuda war the duke had foretold his own fall in battle.

\section{The Environtment in the Hastina State}

At a meeting in the state of hastina was the second scene of the story of Kresna Duta by mastermind ki narto sabdo. The meeting was attended by majesty of hastina, gendari, bisma, druna, sengkuni, salya and Adipati Karna. On the subject, the Duryudana principal asked for input from bisma, druna, sengkuni, and salya, of the hastina state's position and future after the arrival of a delegation from pandawa twice, asking for the return of hastina and Ngendraprasta and the control from kurawa to pandawa, while prabu duryudana suggested how the kurawa would turn raharja. At the meeting, the duryudana first consulted the bisma, followed by druna, sengkuni, and the last of salya.

Bisma suggested to the Prabu duryudana that half the country be given to Pandawa and the other half to the kurawa. The state of the Ngendraprasta should be given to pandawa because it was not for the kurawa. It was proposed that there would be no fighting between pandawa and kurawa over the state. Bisma said: "negara Ngastina prayoga diparo, ingkang separo kagem putu Prabu Duryudana sak kadang kadeyan, ingkang separo paringna ingkang adhi-adhimu Pandhawa, ewadene Negara Ngendraprasta kang nyatane iku darbeke Pandawa sira ora wenang amunasika kang sarta ora wenang angowah-owah sawutuhe nuli balekna marang Pandhawa"

The second opinion after bisma is druna. Druna suggests that the country of hastina toads small towns, such as the gajahoya, the musings, the waranawata, and the gupalawiya. The cities were to be given to the pandavas, while the great kingdom was for the kuravas. Druna says: “.... Kitha alit-alit bawahan negari Ngestina wau kaparingna dhateng ri paduka anak-anak kula Pandhawa, ewadene ing negari Ngastina, negari ingkang ageng kagem paduka anak Prabu Duryudana sumawana kadang Kurawa". Third opinion after druna is sengkuni. Sengkuni is of the opinion: if the dawa wants to get half the hastina state and draprasta and its rations through war. Sengkuni says: “..para Pandawa badhe sembada nampi Ngendraprasta lan negari Ngestina ingkang sepalih, srananipun kedah rinebat sarana peperangan, ... kedah wani nyumerapi muncrating ludira, pecahing dhadha, pegating jangga"..

Based on these Numbers, the sengkuni argued that the many would prevail against the fewer. However, the debate was interrupted by the prabu duryudana, who said that she would listen only to those who agreed. Prabu duryudana says: “.... ing mriki kula naming kepengin midhangetaken pangandikanipun para pangayoman ingkang rumojong lahir-batosipun dhateng pikajeng kula". Then pabu duryudana asks salya for his opinion. As a fourth, salya claims that she disapproves of her views both bisma, druna, and sengkuni. Salya himself is of the opinion that the hastina state and the bakdraprasta and its cargo be given entirely to the burners. Duryudana and the kurawa take over the country of mandaraka, while salya himself will live as pandita. Salya says: “... kula gadhah pemanggih negari Ngestina menika boten perlu dipun ewah-ewah,.... sawetahipun kula aturi maringaken kadang-kadang paduka Pandhawa, ... negari Mandaraka kula caosaken paduka anak Prabu Duryudana”.

After salya expressed his opinion, Adipati Karna responded to his opinion. Although not asked, Adipadi Karna opinion angered salya and challenged Adipati Karna to war. Adipati Karna did not respond to salya's challenge, and incidentally the arrival of Prabu Kresna in Hastina. On that occasion Adipati Karna escaped from a meeting at Hastina. Then the meeting was relayed with the coming of Prabu Kresna as Pandawa's emissary. The meeting does not find a rally point, it mean Baratayuda is coming, it is inevitable [9]. 


\section{Adipati Karna is a knight who knows his duty}

Adipati Karna being a knight and a warlord or a rifle. On the verge of the battle of the Baratayuda, Adipati Karna due to reveal his true identity as a knight. From the data collected by Adipati Karna, it can be categorized as warriors who fulfill their duty wholeheartedly, take responsibility for their actions, and are honest in their actions.

The meeting discussed the future status of Hasitina state and Ngendraprasta and its administration, Adipati Karna being not asked for his opinion, but Adipati Karna kept in mind the opinions of the speakers at the meeting. As the fourth speaker, Prabu Salya finished speaking his mind, which suggested that the Hastina and Ngendraprasta state and all its citations be given to the pandawa, and Duryudana and the kurawa take over the state of Mandaraka, Adipati Karna alarmed, that Prabu Duryudana's stand was shaken [10].

Because of Duryudana seemed to be in a bad position, the duke was obliged to try to inspire Prabu Duryudana with these words: first, Duryudana mustn't trust a person outside the realm of power, let alone a person's inborn nature. In the data states: Ing tata gelar ngrangkul Kurawa nanging kebatosanipun condhong dhateng Pandhawa", means the birth of siding with kurawa but the inner being for pandawa. The point of the quote is, for every entry proposal to be scrutinized, to be scrutinized in a second attitude, and to have a brief understanding of who is friend and who is foe [11]. Means careful, meticulous, firm against friend and foe. Second, the earth state of hastina must be maintained despite sacrifice. In data it states: sadumuk bathuk sanyari bumi, nadyan namung sadumuk jembaring bathuk, nadyan namung sanyari wiyaring bumi, mboten nama mokal kedah dipun tumbas sarana pegating jangga, pecahing dhadha, wutahing ludira", meaning that while only the tip of the index index is the size of the earth's forehead and though only the size of the finger is to be kept until the end of blood. Why is the proverb thus far related to the forehead and the earth?

Both are due to this: the human forehead and the earth in which life forms are a measure of self-respect and dignity. Humans who have no self-respect and no dignity will not be respected by others. Then the duke is here because as a knight it is his duty to maintain honor (pride and dignity) nation and country. Third, the duke, being a warlord, had an obligation to protect the dignity of the majesty of the majesty of the majesty of the hastina state. The duke declared: "Negari Ngastina menika sampun gadhah satunggaling senapati linangkung ingkang trep sarta saget dipun andelaken wonten madyaning paprangan. Menawi ngantos boten trimah para Pandhawa paripaksa angrebat negari Ngastina, Ngendraprasta sakjajahaning kula saget nrenggalani. Ringkesing rembag kawibawan paduka Yayi Prabu Duryudana, jejeg tuwin adeging saka guru negari Ngastina badhe kula tuwak sarana gesangipun Narendra Ngawangga Prabu Karna", If Pandawa does not receive and takes the state of hastina, Adipati Karna will face him. In short, the dignity of the prabu duryudana and the strength of the hastina state will be fortified with the spirit and body of Adipati Karna [12].

\section{Adipati Karna siding with Kurawa by oath and Reputation}

The firmness of Adipati Karna, as described above, can also be found in a dialogue between Adipati Karna and Prabu Kresna dialogue with kunti. In his dialogue with kresna, the assertive righteousness of the king is reflected in his statement that "Inggih Kaka prabu, prasajan kemawon mboten ndadak mawi tedheng aling-aling. Mbenjang Baratayuda menika, kula tetep nyenopateni para Kurawa mengsah lan adhi-adhi kula para Pandhawa", which means saying with all due certainty, there is no hidden that tomorrow the Baratayuda war is to be made as king of kurawa against his brother and sister's enemies of the pandawa. Then the firmness of wau ingity is also found in the rule "Dados inggih sebab makaten wau sampun tetela nadyan geger walik watu kula tetep tumut Kurawa, Kaka prabu", means it's clear that although the 
governor of geger walik watu. Adipati Karna's biography being explained by the prabu kresna, it was in accordance with the request of Adipati Karna of calah, but after being explained and the duke with a clear understanding of its origins, it only served to heighten his sense of accuracy,"Menawi ngaten tetep kula tumut Kurawa, which means Adipati Karna then followed the kurawa. Aside from dialogue with prabu kresna, the firmness of his authority was found in dialogue with kunti, his mother.

The force is found ina statement that says: "Inggih, menawi kula pineksa kedah ngaken, mbok menawi mboten wonten awonipun manawi satunggaling satriya mrasajakaken lampahanipun ingkang sejati, tur ta mboten wonten ginanipun menawi kula ngumpetaken satunggaling lelampahan ingkang nyata. Presajan kemawon, badhe mengsah kula ing tembe boten sanes kejawi namung putra paduka kadang-kadang kula para Pandawa", meaning: if forced to admit, and there is no ugness in being a knight telling the truth about the true way of life, and there is no point in hiding the course of one's life. The truth that would be my enemies would be nothing but the sons of Kunti and also my brothers and burners.

Adipati Karna act of cleavage for siding with kurawa was because of his oath as a knight. In the Kresna Duta as a knight must be guided to his words, who cannot go forth from what was said in the beginning. This is expressed both in dialogue with prabu kresna and in dialogue with kunti. When the dialogue with kunti was addressed, Adipati Karna said, "Kula ngaturaken sembah mawantu-wantu ingkang pungkasan, miwah kula nyuwun pamit saha nyuwun pengestu badhe netepi jejibahan senopati lumawan mengsah, kangjeng ibu", which means I have decided to worship the sembah bekti and ask for a blessing will do the duty as a gun against the enemy. The oath was also conveyed by saying "Dipun menapak-napakna kula boten saget ngempal lan Pandawa. Kula satunggaling satriya kedah setya dhateng ucap kula sekawit”, which means I can't join Pandawa anyway. I'm a knight who must keep the promise of what I've said since the beginning.

Apart from the firmness of kurawa's allegiance to the promise of knights, the Adipati Karna also tried to maintain a good name based on the duties of a knight. In keeping with the reputation of Prabu Duryudana and hastina state, Adipati Karna a knight is risking his life and death. It states Ringkesing rembag kawibawan paduka Yayi Prabu Duryudana, jejeg tuwin adeging saka guru negari Ngastina badhe kula tuwak sarana gesangipun Narendra Ngawangga Prabu Karna", It means with short words of dignity and strength that the hastina state will be fortified with his life as duke because he is Raja Awangga. Beside that, Adipati Karna says: .... kula menika putranipun kangjeng ibu Kunti.

Asma paduka ingkang sampun arum malembar ngebeki jagat menika sampun ngantos banger kasempyok dening pakartining putra ingkang mencla-mencle ing sesanggeman. Kangjeng ibu Kunti sampun ngantos kelepetan dosa, amargi kasempyok dosaning anak ingkang singlar ing kewajiban", which means I am the son of kunti's. This fragrant fragrance of the famous kunti's name permeates the universe should not be provoked by the stench resulting from the position of the mency child of duty. Mother kunti must not fall victim to the sin of a child who cannot fulfill his duty [13].

\section{Conclusion}

From the description above, Adipati Karna was a knight and a warlord or kurawa's rifle. On the verge of the battle of the baratayuda Adipati Karna to reveal his true identity as a knight. That existence is categorized as the three marks of moral value, those relating to duty, responsibility, and honesty. Duty is seen when giving strength to Prabu Duryudana that have a wear spirit and will carry out the duties as an army chief or a warlord. The duty was carried out 
and was the responsibility of a knight who had sworn to keep what he had said. Honesty is a bold proposition.

\section{References}

[1] https://id.wikipedia.org/wiki/Adirata

[2] Suyatno. 2016. "Pemikiran Sukarno tentang Nasionalisme Dalam Perspektif Aksiologi: Kontribusinya Bagi Pendidikan Karakter Bangsa.

[3] Bertens, K. 2011. "Etika”. Jakarta: Graamedia Pustaka Utama.

[4] Magnis-Suseno, Franz. 1984. "Etika Jawa”. Jakarta: Gramedia.

[5] Mudhofir, Ali. 2009. "Kamus Etika". Yogyakarta: Pustaka Pelajar.

[6] Mudhofir, Ali. 1987. "Etika Dasar: Masalah-masalah Pokok Filsafat Moral. Yogyakarta: Kanisius.

[7] Sabdo, Narto. [19..]. "Kresna Duta". Rekaman dalam bentuk file Komputer, 7 Maret 2010.

[8] Satoto, Sudiro dkk. 2012. "Ki Narto Sabdo (Hidup, Idealisme dan Ajarannya)". Sukoharjo: Cendrawasih Asri. Surakarta: Pusat Studi Javanologi (Institut Javanologi), LPPM UNS.

[9] Sukarno. 1964. "Dibawah Bendera Revolusi, Jilid II". Jakarta: Panitya Penerbit Dibawah Bendera Revolusi.

[10] Damono, Sapardi. 1994. Sastra, Politik dan Ideologi. Depok, Pidato Pengukuhan Guru Besar Universitas Indonesia.

[11] Rahyono, F.X. 2012. Studi Makna. Jakarta: Wedhadatama Widya Sastra

[12] Titik Pudjiastuti, 2011. "Manuscripts and cultural identity" dalam Jurnal Wacana. Depok FIB UI.

[13] Oemarjati, Boen. S. 2013. Memaknai Kembara Bahasa dan Budaya. Jakarta. 